\title{
Quantitative vegetation analysis of tree species in the for est adjacent to villages on the periphery of K edarnath wildlife sanctuary
}

\author{
K. S. Puspwan and B. N. Pandey* \\ Government PG College, Lansdowne, Pauri Garhwal - 246139 (Uttarakhand), INDIA \\ *Corresponding author. E-mail: drpandeybn@yahoo.co.in
}

\begin{abstract}
The study was carried out in the forest adjacent to three villages located on the periphery of Kedarnath Wildlife Sanctuary with the objective to evaluate the quantitative characters of tree species of the forest vegetation near these villages in relation to the species diversity, equitability and concentration of dominance of the selected villages. A total of eleven tree species were recorded. While the IVI values ranged from 9.78 to 84.33 , the density values ranged between 0.3 and 1.9 and TBC values between $13.55 \mathrm{~cm}^{2} / 100 \mathrm{~m}^{2}$ and $4080.80 \mathrm{~cm}^{2} / 100 \mathrm{~m}^{2}$. Distribution pattern varied for different species. The recorded values viz. density, Shannon-Weiner Index $(\mathrm{H})$, Concentration of Dominance (cd) and Equitability (Eq) were within the reported range for these types of forests.
\end{abstract}

Keywords: Forest, Vegetation analysis, Quadrat, Dominant species

\section{INTRODUCTION}

Forest is important vegetation. It is not merely an aggregation of trees by chance but it represents an ecosystem, comprising of the vegetation-environment complex, developed through the interrelations among its various elements. It has served not only as natural resources but also it has played the role in preserving the environmental values especially protection to the soil and water regimes. The people in Himalayas have traditionally depended on the nearby forests for their daily needs of fuel wood and fodder. However, rapid increase in human population has increased the pressure on these forests for these and other resources and also by increase in activities like grazing, expansion of agriculture, construction of roads and other structures, etc., causing degradation or destruction of forest cover especially around human habitations. This has also resulted in appearance of various changes in structure, density and composition of the forests. It is estimated that $50 \%$ of the existing forests are under various degrees of problems from soil and site degradation (Prasad and Pandey, 1989). Therefore, survey of natural forest is a required for assessing the changes due to human activities for planning of strategies for its sustainable development. It helps to identify the threats to biodiversity from advancing anthropogenic and climatic factors (Kumar et al., 2004; Sharma and Rana, 2005). Accurate assessment and understanding of the dynamics of plant resources is important for their sustainable management and utilization (Rana et al., 2010).

This study was carried out in the forest adjacent to three villages located on the periphery of Kedarnath Wildlife
Sanctuary with the objective to evaluate the quantitative characters of tree species of the forest vegetation near these villages in relation to the species diversity, equitability and concentration of dominance of the selected villages.

\section{MATERIALS AND METHODS}

Study area: The area under investigation lies in Kedarnath forest division in Rudraprayag district between $30^{\circ}$ to $31^{\circ} \mathrm{N}$ and $79^{\circ}$ to $80^{\circ} \mathrm{E}$. Three sites (villages) selected were: Site I - Sari (elevation $2100 \mathrm{~m}$ above msl); Site II - Krokhi (elevation 1900m above msl) and Site III Makkumath (elevation 1700m above msl). The climate of the study area can be divided into three district seasons, viz. rainy, winter and summer. The total annual rainfall in this area is $248.8 \mathrm{~cm}$, out of which about 75 per cent occurs during the rainy season. The mean monthly temperature ranged from $6.0^{\circ} \mathrm{C}$ (January) to $21.3^{\circ} \mathrm{C}$ (June). The heavy snowfall is experienced during the winter season.

M ethodology: The data was collected by sampling using quadrats of $10 \times 10 \mathrm{~m}$ size. Ten quadrats were randomly placed at each study site. The size and number of the quadrats were determined by the species area curve method (Mishra, 1968). The cbh (circumference at breast height i.e at $1.37 \mathrm{~m}$ above ground) of all the trees in each quadrat was measured and recoded individually for each species for the calculation of total basal cover (TBC). Trees with cbh more than $31.5 \mathrm{~cm}$ only were considered for the study. The data were quantitatively analyzed for frequency, density and dominance as per Mishra (1968). Their relative values were calculated and summed to get 
Important Value Index (IVI) of individual species (Curtis, 1959). The ratio of abundance to frequency (A/F) for different species was determined for eliciting the distribution patterns and on the basis of this ratio, the distribution pattern of species was assessed as regular $(<0.025)$, random $(0.025-0.050)$ and contagious $(>0.050)$ distribution (Curtis and McIntosh, 1950).

The species diversity was determined by using ShannonWiener Information Index (Shannon and Wiener, 1963) as: $\mathrm{H}=\sum \mathrm{pi} \ln \mathrm{pi}$

Where, pi is the proportion of individuals of $i^{\text {th }}$ species and individuals of all the species in a stand.

The concentration of dominance (cd) was determined by Simpson's index (Simpson, 1949) as :cd $=\Sigma(\mathrm{pi})^{2}$

Where pi is the same as for Shannon-Winer Information Index.The equitability or species per log cycle index was determined as per Whittaker (1972) as: $\mathrm{E}=\mathrm{S} /\left(\log n_{\mathrm{i}}-\log \right.$ n)

Where $S$ is the number of species in that stand and $n_{i}$ and $\mathrm{n}_{\mathrm{s}}$ are the density value of most and least important species, respectively.

\section{RESULTS AND DISCUSSION}

A total of eleven forest tree species were recorded from the three study sites. Nine species were recorded from the Site I (Sari) and Site III (Makkumath) while five species from Site II (Krokhi). While five species were common at the three sites, seven species were common at Site I and Site III.

The IVI values ranged from 9.78 (Skimmia arborescence at Site I) to 84.33 (Q uercus floribunda at Site I). On the basis IVI values following dominant tree species were identified at the study sites: Quercus floribunda at Site I, Lyonia ovalifolia (Q . leucotrichophora being the codominant species) at Site II and Q. leucotrichophora at Site III. The associated tree species were: Site I Rhododendron arborium, Q. leucotrichophora, L. ovalifolia, Alnus nepalensis, Daphniphyllum himalayense, Pyrus pashia, Pinus roxburghii and Skimmia arborescence; Site II - P. pashia, A. nepalensis and R. arboretum; and Site III - Q. floribunda, L. ovelifolia, P. pashia, S. arborescence and D. himalayense, $R$. arboreum, $C$ arpinus viminea and M yrica esculenta.

The values of the total density of all the tree species at Site I and III was recorded 7.4 trees $/ 100 \mathrm{~m}^{2}$ (or 740 trees/ ha) while at Site II it was 6.9 trees $/ 100 \mathrm{~m}^{2}$ (or 690 trees/ ha). The density values of different tree species varied from 0.3 trees $/ 100 \mathrm{~m}^{2}$ (Pyrus pashia and Pinus roxburghii at Site I) to 1.9 trees $/ 100 \mathrm{~m}^{2}$ (L. ovalifolia at Site II). The total basal cover across all the species was maximum (76.27 $\mathrm{m}^{2}$ ha) on Site I and minimum (46.94 m/ha) on site II. The total TBC of all the tree species were $7627.16 \mathrm{~cm}^{2} /$ $100 \mathrm{~m}^{2}$ at Site I, $4694.27 \mathrm{~cm}^{2} / 100 \mathrm{~m}^{2}$ at Site II and 5604.29

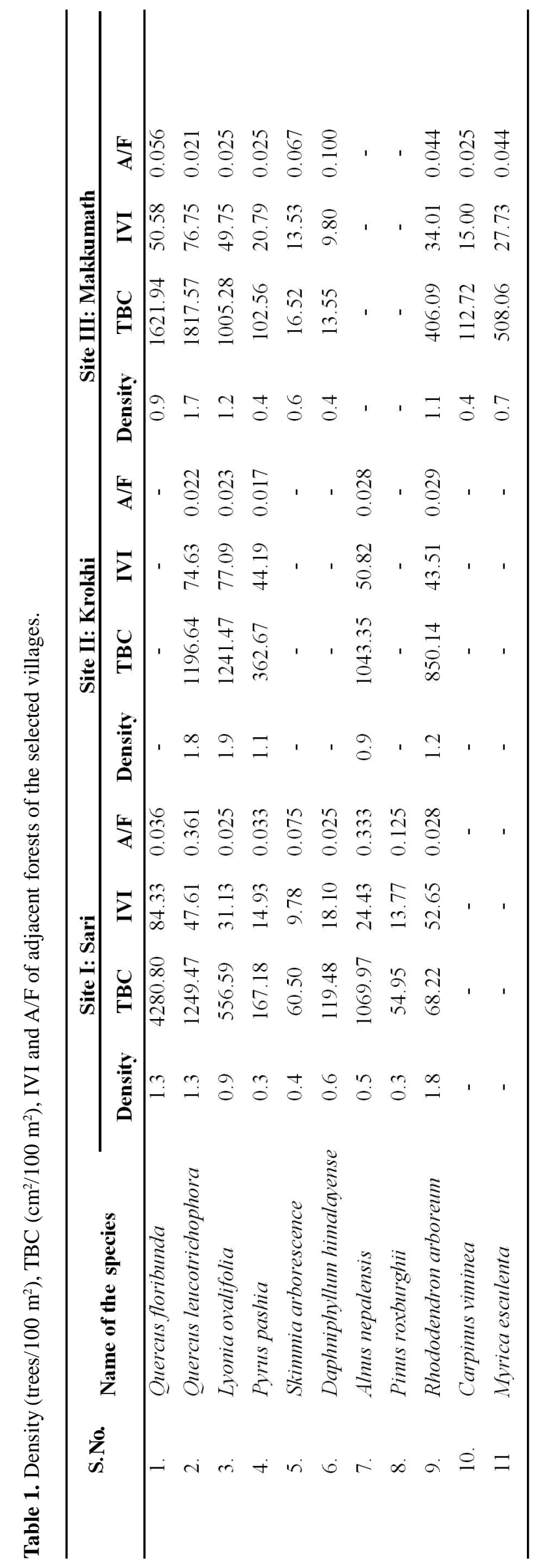


Table 2. Density (trees/100 $\left.\mathrm{m}^{2}\right)$, TBC $\left(\mathrm{cm}^{2} / 100 \mathrm{~m}^{2}\right)$, IVI and A/F of adjacent forests of the selected villages.

\begin{tabular}{llcccccc}
\hline $\begin{array}{l}\text { S. } \\
\text { No. }\end{array}$ & Name of sites & $\begin{array}{c}\text { No. of observed } \\
\text { tree species }\end{array}$ & $\begin{array}{c}\text { Tree } \\
\text { density }\end{array}$ & TBC & $\begin{array}{c}\text { Shannon- } \\
\text { Weiner } \\
\text { Index (H) }\end{array}$ & $\begin{array}{c}\text { Concentration of } \\
\text { dominance (cd) }\end{array}$ & $\begin{array}{c}\text { Equitability } \\
\text { (Eq.) }\end{array}$ \\
\hline 1. & I - Sari & 9 & 7.4 & 7627.16 & 3.59 & 0.56 & 11.56 \\
2. & II - Krokhi & 5 & 6.9 & 4694.27 & 1.96 & 0.44 & 14.48 \\
3. & III - Makkumath & 9 & 7.4 & 5604.29 & 3.21 & 0.14 & 14.32 \\
\hline
\end{tabular}

$\mathrm{cm}^{2} / 100 \mathrm{~m}^{2}$ at Site III. The TBC values of different tree species ranged from $13.55 \mathrm{~cm}^{2} / 100 \mathrm{~m}^{2}$ (D aphniphyllum himalayense at Site III) to $4280.80 \mathrm{~cm}^{2} / 100 \mathrm{~m}^{2}$ (Q . floribunda at Site I). The values for basal cover and density for similar type of forests as reported by different authors vary from 5.61 to $59.39 \mathrm{~m}^{2}$ ha and 350 to 2080 trees/ha, respectively (Saxena and Singh, 1982). The density values were similar to those reported earlier. However total basal cover values were comparatively higher.

It is evident from the ratio of abundance to frequency $(\mathrm{A} / \mathrm{F})$ that all the species at Site I were randomly distributed except Pinus roxburghii and Skimmia arborescence having regular and contagious distribution, respectively. At Site II Rhododendron arborium and Alnus nepalensis were found randomly distributed whereas the three species were regularly distributed. At Site III Quercus leucotrichophora has regular distribution while $Q$. floribunda, Skimmia arborescence and Daphniphyllum himalayense have contagious distribution. The other five species were randomly distributed. The distribution pattern depends on the local habitat differences, daily and seasonal weather changes, reproductive processes and magnitude of biotic interference such as grazing and lopping in the natural forest stands (Odum, 1971). Distribution pattern of species is important for evaluating the complexity and resources of the forests. The tree species which grow in clumps are, in general, better adapted for intra-specific competition than inter-specific competition, therefore, the management of such forests require special attention (Thakur and khare, 2009).

The values of species diversity, concentration dominance and equitability for all the three selected sites have been presented in Table 2 . The diversity values $(\mathrm{H})$ in the present study were similar to those reported $(0.33-2.95)$ for most of the Central Himalayan Forests (Saxena and Singh, 1982; Ralhan et al., 1982; Upreti et al., 1985; Baduni and Sharma, 1996. The values recorded for concentration of dominance (cd), ranging from 0.1401 to 0.5607 , were also within the reported range for these types of forests and are also in conformity with those reported in tree layer $(0.11-0.93)$ for oak forest in adjacent Kumaun Himalaya ( Tiwari and Singh 1985; Saxena and Singh, 1982).

The data had indicated that the forests of all the studies villages are in mature state. The IVI values indicate that the dominance in the forests is shared by associated species also. High IVI indicates the dominance and ecological success of species on account of its good power of regeneration and greater ecological mamplitude (Thakur and Khare, 2009). The diversity increases with an increase in increasing species richness. It is an established fact that the tree diversity increases with the moderate levels of disturbances. The density values on the present studies sites were in the range of earlier reported values, but total basal cover values were not in the reported range but comparatively higher. It may be due to the biotic pressure i.e. felling and lopping by the villagers for their daily needs of fuelwood and fodder. The forests under study are under constant utilization pressures. However, the species show resilience to these pressures viz. anthropogenic factors, grazing and fire.

\section{REFERENCES}

Baduni, N.P. and Sharma, C.M. (1996). Effect of aspect on the structutre of some natural stands of Cupressus torulosa in Himalayan moist temperate forest. Proc. Ind. Nat. Sci. Acad., 62(B): 345-352.

Curtis, J.T. (1959). The vegetation of Wisconsin University. Wisconsin Press, Madison.

Curtis, J.T. and McIntosh, R.P. (1950). The interrelations of certain analytic and synthetic phytosociological characters. Ecology, 31: 434-455.

Kumar, M., Sharma, C.M. and Rajwar, G.S. (2004). A study on the community structure and diversity of a sub-tropical forest of Garhwal Himalayas. Indian For., 130: 207-214.

Mishra, R. (1968). Ecology Work Book. Oxford and IBH Publ. Co. Calcutta.

Odum, E.P. (1971). Fundamentals of Ecology. W.B. Saunders Co., Philadelphia.

Prasad, S.K. and Pandey R.K. (1989). An observation on the effect of closure for rehabilitation of degraded forest lands A case study of protected and unprotected wasteland at Bhopal. J. Trop. For., 5: 128-137.

Ralhan, R.K., Saxena, A.K. and Singh, J.S. (1982). Analysis of forest vegetation at and around Nainital in Kumaun Himalaya. Proc. Ind. Nat. Sci. Acad., 48(B): 122-128.

Rana, J.C., Singh, A., Sharma, Y., Pradheep, K. and Mendiratta, N. (2010). Dynamics of plant resources in Western Himalayan region of India - watershed based study. C ur r. Sci., 98(2): 192-203.

Saxena, A.K. and Singh, J.S. (1982). A phytosociological analysis of wood species in forest communities of a part of Kumaun Himalaya. Vegetation, 50: 3-22. 
Shannon, C.E. and Wiener, W. (1963). The Mathematica Theory of Communication. University Illinois Press, Urbana.

Sharma, B.D. and Rana J.C. (2005). Plant genetic resources of Western Himalaya - status and prospects. Bishen Singh Mahendra Pal Singh, Dehradun, India.

Simpson, E.H. (1949). Measurement of diversity. Nature, 163: 688 .

Thakur, A.S. and Khare, P.K. (2009). Composition of forest vegetation and floristics of Sagar district, Central India. J . Ind. B ot. Soc., 88 (1\&2): 11-17.
Tiwari, J.C. and Singh, S.P. (1985). Analysis of woody vegetation in a mixed oak forest of Kumaun Himalaya. Proc. Ind. N at. Sci. Acad., 51(B): 232-247.

Upreti, N., Tiwari, J.C. and Singh, S.P. (1985). Oak forest of Kumaun Himalaya - composition, diversity and regeneration. Mt. Res. Dev., 5: 163-174.

Whittaker, R.H. (1972). Evolution and measurement of species diversity. Taxon, 21: 213. 